\title{
Destructive Arthritis of the Hand After Diving
}

FLORENTINA BERIANU, Rheumatology Fellow; WILLIAM GINSBURG, Associate Professor of Medicine, Department of Medicine; STEPHAN TRIGG, Associate Professor of Orthopedics, Department of Orthopedics; BENJAMIN WANG, Assistant Professor of Medicine, Department of Medicine, Mayo Graduate School of Medicine, Mayo Clinic, Jacksonville, Florida, USA. Address correspondence to Dr. F. Berianu, 4500 San Pablo Road, Jacksonville, Florida 32224, USA. E-mail: berianu.florentina@mayo.edu. J Rheumatol 2014;41:2486; doi:10.3899/jrheum.140567

Destructive infectious arthritis can result after joint impact, even without obvious trauma.

A previously healthy 27-year-old woman woke up with extreme pain, redness, and swelling in her left hand. Redness and swelling had progressed rapidly from the red line on the first day to the blue line on the second day, and extended farther the next day (Figure 1A). She had no fever, but reported extreme pain and an inability to use her left hand and wrist. Three days prior, she went diving and hit the marine flora, but denied any penetrating trauma. The radiograph of her left hand showed soft tissue swelling at the wrist, but no other abnormalities (Figure 1B). C-reactive protein was noted at $56 \mathrm{mg} / \mathrm{l}$ and erythrocyte sedimentation rate at $28 \mathrm{~mm} / \mathrm{h}$. Blood culture, synovial fluid, and tissue cultures were negative, including mycobacteria. Her immunologic work up was unrevealing.

Sixty $\mathrm{mg}$ of prednisone decreased the swelling, but the patient continued to experience pain, and she was not able to use her hand. No other joints were affected. The patient received vancomycin IV and responded with a complete resolution of the swelling, redness, and pain in her hand and wrist. The vancomycin treatment was given for a month. The subsequent radiograph of the left hand 6 months later showed extensive erosive arthritis with ankylosis at the carpal level (Figure 1C). She has maintained a limited range of motion in her left hand and wrist. The acute onset after diving and the marked response to antibiotics make this episode a likely example of destructive infectious arthritis $^{1,2}$.

\section{REFERENCES}

1. Cook PP, Siraj DS. Bacterial arthritis. In: Firestein GS, Budd RC, Gabriel SE, McInnes IB, O'Dell JR, editors. Kelley's textbook of rheumatology, 9th ed. Philadelphia: Saunders; 2012:1801-14.

2. Fangtham M, Baer AN. Methicillin-resistant staphylococcus aureus arthritis in adults: case report and review of the literature. Semin Arthritis Rheum 2012;41:604-10.
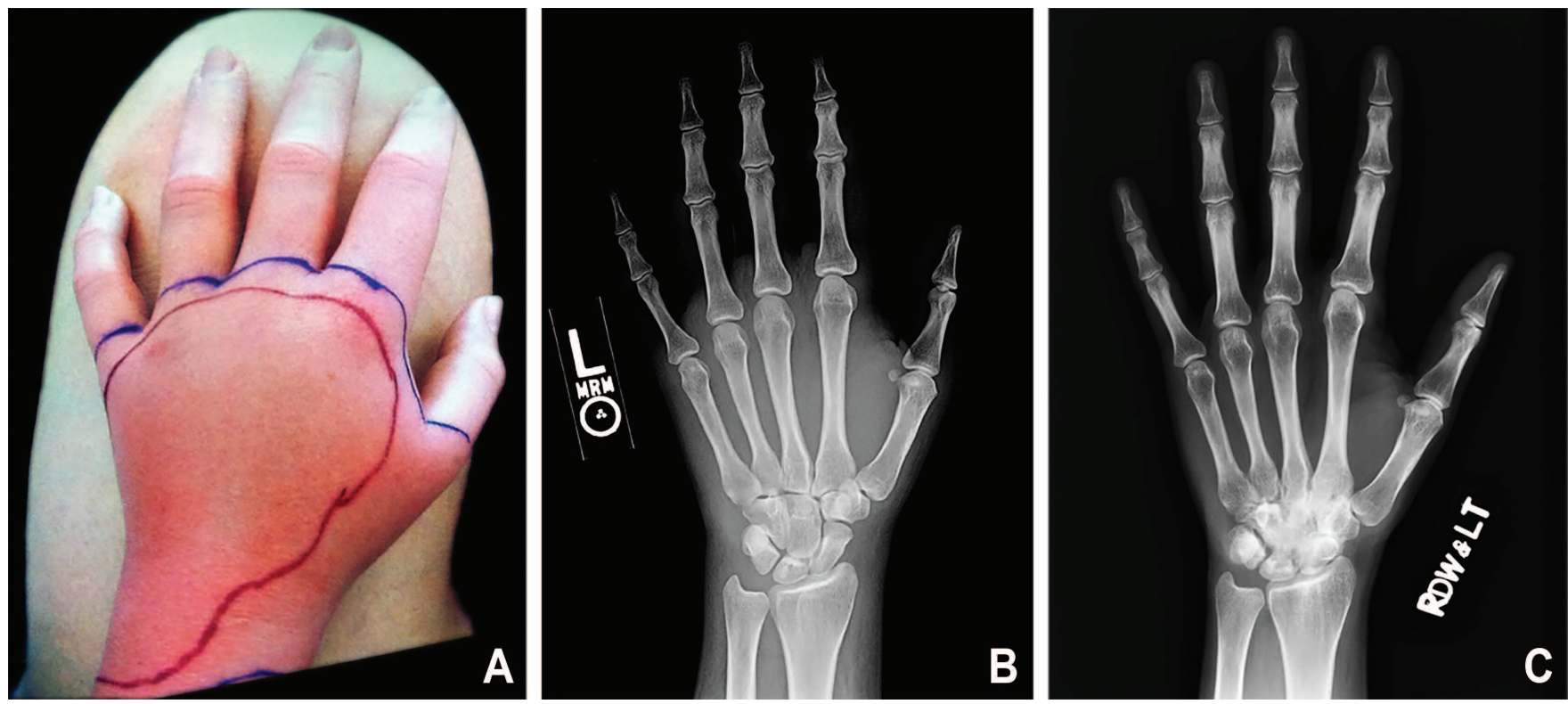

Figure 1. A. Redness and swelling had progressed rapidly from the red line on the first day to the blue line on the second day. B. Radiograph of left hand showed soft tissue swelling at the wrist, but no other abnormalities. C. The subsequent radiograph of the left hand 6 months later showed extensive erosive arthritis with ankylosis at the carpal level.

Personal non-commercial use only. The Journal of Rheumatology Copyright @ 2014 . All rights reserved. 